\title{
Corporate Social Responsibility Practices in Banking Industry
}

\author{
Dr Helen Wong, DBA, CPA, FCCA, CPA (Canada) (Corresponding Author) \\ The Hong Kong Polytechnic University, Hong Kong Community College \\ 9 Hoi Ting Road, Kowloon, Hong Kong \\ Tel: 852 -3746-0228Ｅ-mail: cchelen@hkcc-polyu.edu.hk
}

\begin{abstract}
Dr Raymond Wong,DBA, CMA, MCIM
The Chinese University of Hong Kong, School of Accountancy

No. 12 Chak Cheung Street, Shatin, New Territories, Hong Kong

Tel: 852-3943-8552Ｅ-mail: raykhwong@baf.cuhk.edu.hk
\end{abstract}

\author{
Received: June 25, $2015 \quad$ Accepted: July 11, $2015 \quad$ Published: July 11, 2015 \\ doi:10.5296/jmr.v7i4.7894 URL: http://dx.doi.org/10.5296/jmr.v7i4.7894
}

\begin{abstract}
Corporate social responsibility is getting more attention from public and business. Besides profit, public and business also concern whether corporations are operating socially responsible nowadays. Although the key objective of a business corporation is to earn maximum profits for shareholders or owners, it is expected to conduct its operations in a manner to fulfill its social obligations. Big corporations are expected to have more corporate social responsibility practices because they have more resources. This study is to examine the current practices of corporate social responsibility in three biggest banking corporations in Hong Kong. The selected banks are ranked top three in terms of total assets and net profit after tax in a banking survey of 2013. Similarities and differences of their practices are discussed in the study. The study provides insights to other banks in taking up the corporate social responsibility, such as resources allocation and action plan towards better community and environment etc. Furthermore, their practices may also act as references to other industries.
\end{abstract}

Keywords: Banking, Corporate social responsibility, Social, Economic, Environment, Sustainability 


\section{Introduction}

Although the primary objective of business is to earn maximum profits for shareholders or owners in ethical way, it is also expected to operate in a way that fulfills social obligation. Companies have corporate social responsibility (CSR) practices commit themselves operating in a way to benefit the community at large (Olivia, 2011). Businesses nowadays are expected to operate ethically and in a way fulfilling social obligations. CSR aims to embrace responsibility for corporate actions and to encourage a positive impact to the environment and stakeholders. Proponents suggest that companies can increase long-term profit by operating with a CSR perspective, while critics argue that CSR distracts business from economic consideration. With the growing importance of CSR nowadays, some governments or international associations have set guidelines to listed companies on reporting CSR initiatives. This study concentrates on examining CSR practices of banks because CSR involves doing good to different stakeholders, not just shareholders, which is a more comprehensive approach in companies' strategies.

\section{Literature Review}

The initial period for the emergence of CSR belief is in around 1920s (Hoffman, 2007). At that time, business started to be expected to possess social responsibility rather than an individual. In the early development, many take an instrumental approach to CSR. The most famous advocate is Milton Friedman. Friedman (1962) argues that it would be unethical for the company to do anything other than deliver profits to the investors of the company. Friedman also argues that the manager, as an employee of the company, has an ethical obligation to fulfill his role in achieving the expectations of his employers. The instrumental perspective states that the only obligation of a company is to maximize profits for its shareholders in providing goods and services which meet customers' needs (Ghillyer, 2014).

Until 1980s, the emerging of stakeholder theory states business has to concern both internal and external stakeholders (Freeman, 1984). The stakeholder theory emphasizes that both shareholders and all stakeholders' interests should have equal importance. The social contract approach states a company has an obligation to society over and above the expectations of its shareholders (Ghillyer, 2014). The modern social contract approach argues that as the company depends on society for its existence and growth, the company has obligation to the society rather than just to shareholders. Company has to recognize the needs of all stakeholders (including customers, employees, shareholders, vendor partners and community partners etc.) rather than just shareholders. Nowadays, CSR is generally defined as the actions of a company aim at achieving social benefits over and above maximizing profits for its shareholders and meeting legal obligations.

Different companies may have different level and form of CSR. There are three distinct types of CSR - ethical, altruistic, and strategic (Ghillyer, 2014). Ethical CSR is the purest form of CSR in which the company pursues a defined sense of social conscience in managing its financial responsibility to shareholders, legal obligation to the society, and its ethical responsibility to do right things for its stakeholders. Altruistic CSR is a philanthropic form of CSR in which the company has specific initiatives to give back to the company's community 
or country, for example, giving donation to needed. Strategic CSR is also a philanthropic approach to CSR in which company's action will generate the most positive publicity or goodwill for the company while it also runs the greatest risk of being perceived as self-serving behavior on the part of the company. For instance, Ford Motor spent millions on an advertising campaign to raise awareness of the need for booster seats for children over 40 pounds and under 4 feet 9 inches and gave away a million seats as part of the campaign. Such booster seat campaign can be considered as a way to position Ford as the auto manufacturer that cares about safety of its passengers and drivers (Ghillyer, 2014).

\subsection{Benefits \& Costs of having CSR}

Proponents of CSR argue that company can benefit from having CSR, such as enhancing reputation, generating greater employee and customer loyalty and retention (Lance, 2001). Firstly, CSR can generate reputation and then create business value to the social responsible company (Bebbington et al., 2008). CSR can maintain customer loyalty which is important for company because it is more costly to attract new customers than to retain existing customers (Mandhachitara\&Poolthong, 2011). Secondly, adopting CSR can make company more profitable. Company can increase sales revenue by gaining customer support and reduce cost by having environmental friendly approach in production. More tax reduction will be obtained by using environmental friendly machinery or making charitable donations (Doukakis et al., 2005). Having environmental-friendly production can also achieve cost efficiency position (Gyves\& Higgins, 2008). Thirdly, CSR has positive impact on strategic decision of the company. CSR facilitates product differentiation strategy to be successful and a higher price can be charged for the product (Cruz \&Boehe, 2008). For instance, differentiating through the use of CSR resources like recycled products or organic pest control (McWilliams \& Siegel, 2001). Company can also gain competitive advantage since the company shows the uniqueness of the value to community (Holme, 2010).

However, implementing CSR is not without costs. Firstly, using new machinery in production will involve intensive capital investment which may then result in liquidity problem (Yeoh, 2007). Higher capital cost may shake the position of cost leadership of the company (Lanoizelee, 2011). Secondly, company may hire additional staff to advocate and conduct CSR through affirmative action, community outreach, and improved labour relations (McWilliams \& Siegel, 2001), therefore higher wages and benefits have to be provided. Thirdly, CSR may require higher cost of materials or inputs from suppliers. For instance, Body Shop purchases special ingredients and formulas that have not been animal tested (McWilliams \& Siegel, 2001).

\subsection{CSR in Business}

CSR has become a more and more important concern in today's business world. It is a business philosophy covering a wide range of aspects such as human rights, environmental protection, and well-being of employees and other stakeholders; and its ultimate aim is the sustainability of the business. 
The Global Reporting Initiative (GRI) reviews and provides most up-to-date guidance for effective sustainability reporting. The most recent version of Sustainability Reporting Guidelines is G4. G4 is designed to be applied universally to all organizations including small and large around the world. According to the G4, it suggests the areas for general standard and specific standard disclosures. General standard disclosures include strategy and analysis, organizational profile, material aspects and boundaries, stakeholder engagement, report profile, governance and ethics and integrity. Specific standard disclosures include management approach, indicators on economic, environmental and social aspects.

Besides GRI, regulatory bodies in different countries also encourage CSR via various routes. Some countries have already included CSR in their corporate laws. For instance, the Company Act of United Kingdom requires companies' directors' report to include information about companies' policies about environmental matters, employees and other social and community issues. The Company Law of China requires company to observe social morals and commercial ethics and assume social responsibility in its operational activities. The Limited Liability Companies Law requires companies in the field of natural resources to practice environmental and social responsibility.

Oxfam Hong Kong (OHK), an international development and relief agency working to reduce poverty and injustice, urged the government to rewrite the Companies Ordinance in 2010 advocating the necessity to increase companies' disclosure on non-financial information such as social and environmental performance (OHK, 2010). OHK believes both voluntary efforts and mandatory measures imposed by regulators will create and sustain the momentum of CSR in Hong Kong. OHK submitted a proposal to the Hong Kong Stock Exchange on environmental, social and governance reporting in 2012.

Moreover, various world exchanges have put continuous effort in promoting CSR. FTSE, a subsidiary of the London Stock Exchange, is quite active in developing sustainability related information products and services, such as launching a global environmental markets industry classification system, FTSE CDP Carbon Strategy Index Series, and FTSE4Good ESG Ratings service etc. Singapore Exchange provides Sustainability Reporting Guide to listed companies for sustainability reporting. In China, there are sustainability indices - the SSE Social Responsibility Index in Shanghai, SZSE Corporate Social Responsibility Index in Shenzhen, and the SSE Sustainable Development Industry Index in Shanghai. State-owned enterprises in China controlled by the Central Government have to publish CSR reports from 2012 onwards.

In Hong Kong, the Hong Kong Exchanges and Clearing Limited (HKEx) promotes CSR practices and sustainable investment in Hong Kong market. HKEx has provided Environmental, Social and Governance (ESG) Reporting Guide to listed companies in Hong Kong. The Guide covers four areas: workplace quality, environmental protection, operating practices and community involvement. The Guide is a recommended practice and the HKEx plans to raise the obligation level of some recommended disclosures in the Guide to comply or explain by 2015. Seminars and workshops are organized for listed companies in due course. Listed companies are also encouraged to adopt GRI guidelines on sustainability 
reporting. According to the report by HKEx (2011), HKEx itself took the lead and has adopted the GRI guidelines for preparation of its annual CSR report since 2009. According to the Listing Rules in Hong Kong, the IPO applicant must disclose whether the company has any material breach of laws and regulations and any ESG issues that might be material to an investor's assessment of the IPO activity.

\subsection{CSR in Banking Industry}

Some scholars consider CSR is a public relations issue. Frankental P. (2001) suggested that CSR is an invention of public relations and CSR can only have real substance if it considers all stakeholders and it is reinforced by changes in company law or rewarded in financial markets.

Some previous studies suggested there is a positive link between corporate social performance and financial performance, such as Stanwick and Stanwick (1998) and Preston and O'Bannon (1997). In the study of Simpson and Kohers (2002), the result indicated there is a strong positive relationship between corporate social performance and financial performance in banking industry. The costs of being socially responsible are outweighed by improvement in productivity or other associated financial performance indicators, and the resources used to be socially responsible are not so high to make the bank unprofitable. However, some studies suggested that care should be taken in specifying the variables in the regression model in order to have valid conclusion.

In the study of Yeung (2011), the result suggested that in order to become a social responsible bank, the banks has to establish a mindset of risk management, business ethics and corporate social responsibility through internal management of people and process; understand complex financial products through internal management of people and process and external management of economic situation for the benefit of stakeholders; protect the rights of customers with setting up channels for customers to address complaints.

In The 3Cs for Responsible Banking in Asia and the Pacific: Corporate Governance, Corporate Social Responsibility and Corporate Sustainability of United Nations Economic and Social Commission for Asia and the Pacific (ESCAP), it highlighted two areas of potential CSR focus for banks and financial institutions: small and medium-size enterprises (SME) access to financing and green business financing. According to this report, banks have begun to pay more attention on CSR, adhere to international codes of conduct and offer financial products that take account of sustainability issues; but there is still significant room for improvement.

\subsection{CSR in Banks in Hong Kong}

In 2014, KPMG Hong Kong conducted a banking survey in Hong Kong. Although banks are having healthy growth in both assets and net profit, the banking sector is facing challenges such as regulatory pressure and continued uncertainty regarding US, Europe and China economies (KPMG, 2014). There are licensed banks, restricted license banks, deposit-taking companies and foreign bank branches in Hong Kong. Based on the KPMG's survey, this study picks the top 3 licensed banks in terms of total assets and net profit after tax to 
investigate their CSR practices. The top 3 licensed banks are Hong Kong and Shanghai Banking Corporation (HSBC), Bank of China Hong Kong Limited (BOCHK), and Hang Seng Bank Limited (Hang Seng). It is interesting to examine the similarities and differences in the practice of CSR among the top 3 banks in Hong Kong which can provide insights to other banks in taking up CSR.

With the increasing importance and demand of CSR, it is worthwhile to have study on CSR practices in banking sector. This study aims at investigating:

1. the current practices of CSR in the top 3 banking corporations rated by KPMG Hong Kong Banking Survey 2014;

2. the similarities and differences in the practices of CSR among the top 3 banks;

3. resources implications on having CSR; and

4. insights provided to other banks and regulators.

\section{Research Method and Analysis}

This study will examine secondary data collected from recent websites, annual reports, corporate social responsibility reports and sustainability reports of HSBC, BOCHK and Hang Seng. The CSR practices of these 3 banks will be highlighted and compared.

\subsection{Hong Kong \& Shanghai Banking Corporation Limited (HSBC)}

HSBC believes that making profit is not the only concern of the company. To be a sustainable bank, HSBC provides customers with their required products and services, manages the impact the company has on society and environment, invests in the future of its employees and community. HSBC has put great focus in four aspects: environmental efficiency, climate business, sustainability risk, and community investment.

a. In regard to environmental efficiency, the bank's activities have impact on the environment such as its buildings and information technology systems. To provide services in an environmentally friendly way, the company works hard to reduce energy consumption, waste and $\mathrm{CO} 2$ emissions. For instance, reducing annual employee carbon emissions from 3.5 tonnes to 2.5 tonnes by 2020 , reducing annual energy consumption per employee by $1 \mathrm{MWh}$, recycling 100 percent of office and electronic waste, increasing self-generated electricity from 0 to 5 percent, increasing energy consumption from renewables from 24 percent to 40 percent, using Leadership in Energy and Environmental Design (LEED) buildings, promoting paperless banking by giving customers access to internet banking, and having sustainable travel by using video-conferencing and webinars. In 2013, HSBC trained an additional 255 senior managers as part of its Sustainability Leadership Programme, bringing the total number to 627 . Besides, more than 2,800 employees are trained and acted as ambassadors for climate change.

b. In the area of climate business, HSBC supported low-carbon transport solutions, renewable-energy projects and clean-tech businesses. It has been rated the number one company for integrated climate change by Thomson Extel awards for Pan-European 
investment research for the past three years. HSBC's projects are not just limited to a single place, for instance, it structured a project finance deal to fund a 49.5-megawatt wind farm in Jilin Province of China. It also structured finance arranger for Johannesburg's Rea Vaya Bus Rapid Transit Project, a low-polluted and high-speed bus network in Africa.

c. Regarding sustainability risk, HSBC takes into account adverse impact on local communities and environment when doing its business. HSBC identifies key sectors where such impacts are likely to arise and creates sector policy to guide the way it operate in these sectors. For instance, it has Forestry Policy, Agricultural Commodities Policy, Chemicals Industry Policy, Defence Equipment Sector Policy, Freshwater Infrastructure Policy, and Mining and Metals Sector Policy etc.

d. In the area of community investment, it includes education, environment, volunteering, and donation. On education side, HSBC raises environmental awareness and provides scholarship and financial literacy classes. On environment side, HSBC partners with environmental organizations to motivate actions and build awareness to help ensure future generations inherit a greener environment. Staff members of HSBC volunteer helping the elderly, the young, and the mentally-disabled, and providing mentorship to students and volunteer activities. HSBC has won the Champion of the Highest Service Hour Award organized by Social Welfare Department of Hong Kong for seventh time since 1998. The Award recognizes employee's volunteering work contributed to the community. HSBC also donates huge sum of money to variety of causes in Hong Kong and around the world. It establishes the Hong Kong Bank Foundation which manages HSBC's donations in Hong Kong and mainland China.

HSBC's CSR practices cover a wide range of activities and endeavors. In fact, HSBC has been ranked number one in Oxfam Hong Kong's CSR survey in both 2008 and 2009 when Oxfam Hong Kong conducted thesurvey among Hong Kong listed companies in these two years.

\subsection{Bank of China (Hong Kong) Limited (BOCHK)}

To fulfil social responsibility is important for creating and maintaining long-term core competitiveness, forging closer relationship with stakeholders and enhancing brand value. Having this belief in mind, BOCHK conducts its business in a responsible way and has been named as a Caring Company by the Hong Kong Council of Social Service for 11 consecutive years and included in its List of Barrier-free Companies newly launched in 2013, and has been included as a constituent of the Hang Seng Corporate Sustainability Index Series for 4 years.

CSR is an integral part of BOCHK's business operations and is incorporated into her strategy. In her CSR Report 2013, 6 areas have been highlighted: corporate governance, stakeholder engagement, people, community, environment, and supply chain.

a. For corporate governance, BOCHK strictly abides by the regulations and laws in Hong Kong, and observes the rules and guidelines issued by various regulatory bodies, such as Hong Kong Monetary Authority, Hong Kong Securities and Futures Commission, and the 
Stock Exchange of Hong Kong. Moreover, various Board Committees are set up: Audit, Nomination and Remuneration, Risk, Strategy and Budget, and Management Committee, to take care of relevant matters. A Board Diversity Policy was formulated in 2013 to promote Board efficiency and corporate governance standards of the company and to be in line with the new Corporate Governance Code on board diversity.

b. BOCHK recognizes the importance of engaging with stakeholders: customers, employees, shareholders, investors, government and regulators, and suppliers, in achieving her business goals and upholding her CSR commitment.

BOCHK provides customer-centric banking services to address customers' needs. It collects feedback from customers through survey, focus group discussion, and communication between customers and front-line staff. It also has a Customer Personal Data Protection Policy to guide departments in collecting and protecting customer information properly.

For employees, staff performance is reviewed annually and semi-annually. It also has a formal complaint platform and mechanisms to collect employee's complaints and feedback. Its development will share with staff through staff magazine and internal website. Senior management also makes regular branch visits to collect feedback from staff and customers.

For shareholders, various channels have been used to collect feedback from shareholders and shareholders also have rights to obtain available information of the company, make proposals at annual general meeting and nominate a person for election as a director.

For investors, the company held numerous meetings, such as road shows, investor conferences, company visits and conference calls, with investors and analysts to discuss the company's strategies and business initiatives. Financial information, historical data, business strengths, weaknesses, growth opportunities and threats are also discussed.

For government and regulators, the company follows the laws and regulations strictly and observes the rules and guidelines issued by regulatory authorities. Close communication is maintained with regulatory authorities. The company also actively participates in various committees of governmental or industrial bodies.

For suppliers, the company has experienced procurement staff to communicate standards and requirements to suppliers and regular review is conducted to ensure suppliers meet company's standards.

c. Regarding people (employees), the company treasures people as the most important asset. The company aims at providing a people-oriented culture to employees, for instance, having a fair and transparent recruitment policy, providing good working conditions and occupational development opportunities for employees, and providing open and transparent communication channel for employees etc. There is Staff Code of Conduct to govern workplace practice. The company provides competitive remuneration packages and incentive schemes to reward employees with good performance. The Corporate Safety Division also offers training classes to employees to ensure a safe working environment is provided. To have a work-life balance, the company organizes a range of recreational activities for staff; 
free and regular body checks and counselling services are also provided. Staffs are encouraged to participate in volunteer services. The company established the Dynamic Volunteer Team and set guidelines for the Team. Regarding talent managementand staff development, the company set up a Talent Management Division to be responsible for various staff development and recruitment. The company's training and development programmes are recognized by Hong Kong Council for Accreditation of Academic and Vocational Qualifications. To enhance the working environment continuously, the conducts online staff engagement survey to collect staff opinion.

d. The company has been serving the community with a dedication to develop harmonious relationship with community members. Easily accessible banking services are provide to customers, for instance, 24-hour self-service banking centers and ATMs with special features and functions for disabled customers. To better serve senior citizens, the company offers the Reverse Mortgage Programme encouraging and educating senior prepare their retirement the programme provides people aged 55 or above the flexibility to use their self-occupied and non-mortgaged residential properties as collateral in return for stable annual payments. To support charitable organizations, the company waives administration fee for donations made through the company to selected charitable organizations. The company also donates computers to the Caritas Computer Workshop and Hong Kong Red Cross to support relief works and sponsors the Ocean Park Halloween. To students, scholarships and internship opportunities are provided to them. The company has also been a patron of sports in the community and supported the Hong Kong Island and Kowloon Regional Inter-School Sports Competition for 11 consecutive years already. The company gets the Gold Award for Volunteer Service for 4 consecutive years by Social Welfare Department and the Caring Company for 11 consecutive years by the Hong Kong Council for Social Service.

e. The company also commits to environmental sustainability. Before making lending decision, the company evaluates the potential positive and negative social or environmental impact of the financed projects. For instance, loans are extended to companies to develop new energy sources, renewable energy and water conservation projects. The company launched the Energy Efficiency Loan Scheme with two electricity companies in Hong Kong to offer loans to industrial and commercial customers for energy saving initiatives. Besides helping others, the company itself continues to increase energy efficiency and implement water saving measures in the company and promote green banking service. For instance, LED lighting and T5 fluorescent tubes are used in office, e-statement service and internet / mobile banking is encouraged. The company also adopts e-performance system, uses recycle paper, purchases furniture items which subject to green specifications of the Environmental Protection Department of the Government, and sponsors the Green Monday School Programme. The company gets the Certificate of Quality Water Recognition Scheme for Building by Water Supplies Department and the Excellence Class Indoor Air Quality Certificate by Environmental Protection Department.

f. Regarding supply chain management, the company has policies outlining the expectation about suppliers. A Sustainable Procurement Policy and a Supply Chain Code of Conduct set 
clear guidelines for suppliers. On-site visits and interviews of suppliers are conducted to make sure suppliers meet the company's standards.

\subsection{Hang Seng Bank Limited (Hang Seng)}

Hang Seng is Hong Kong's leading domestic bank. Back in 2010, Hang Seng was the first local bank to employ the internationally recognized Global Reporting Initiative sustainability reporting guidelines. Hang Seng uses a variety of top-down and bottom-up approaches to actively and effectively engage her stakeholders which include customers, staff, shareholders, suppliers, business partners, regulators and the community, and has put great efforts in four areas which mentioned in her Corporate Sustainability Report 2013: corporate governance and business, people, environment, and community investment.

a. Regarding corporate governance, her Board of Directors commits to high standards of integrity and ethics. Matters relating to risk management governance, internal control, policies and practices on compliance with legal and regulatory requirements are considered by the Board. The bank follows the guidelines and requirements set by the Hong Kong Monetary Authority and the Stock Exchange of Hong Kong Limited. The Board has set up five committees - Executive, Audit, Remuneration, Risk, and Nomination, to oversee different important aspects. Frontline staffs are also operating ethically, honestly and with full accountability to maintain the corporate reputation.

b. In regard to people, Hang Seng has strong emphasis on customers, suppliers, and staff. For customers, Hang Seng has a standardized complaint handling procedure to ensure customer feedback is dealt in an efficient manner that abides by the service pledges. The bank has careful planning in her network of outlets and considers special needs of the community, such as introducing "Social Caring Counters" at selected branches for elderly, disabled people and customers with special needs. In providing services to customers, the bank provides clear, transparent and balanced information to customers; and the bank ensures the privacy of customers' personal information. The bank has formulated a set of "Privacy Principles" to guide staff in protecting customer details. Hang Seng also offers a wide range of products specifically for small and medium-sized enterprises (SME) which will create more new employment opportunities. For instance, the Hang Seng Green Financing Scheme provides funding for Hong Kong-owned factories in the Pearl River Delta Region to acquire green equipment which can enhance energy efficiency and reduce pollution. To help customers in difficulty, the bank provides assessment and advisory services to help them get back on track. This may involve rescheduling debt based on new cash flow projections and giving grace period to give customers time to execute a longer term recovery strategy. The bank is also working in partnership with several non-governmental organizations, such as Caritas Family Crisis Support Centre and Tung Wah Groups of Hospitals, to help individuals in financial difficulty.

For suppliers, Hang Seng has strict standards for assessing suppliers, such as requirements on environmental, social and ethical practices. Suppliers have to comply with Hang Seng's supplier sustainability standards. For instance, suppliers are required to comply with her Ethical and Environmental Code of Conduct for Suppliers of Goods and Services. Suppliers 
have to respect human rights of employees and individuals, and to comply with relevant legislation and regulations in the communities they operate. Suppliers also need to complete a questionnaire covering environmental issues during the tender process. Hang Seng has stringent procedures governing staff conduct when handling procurement issues. E-procurement systems are used to reduce paper consumption and lead times as well as enhance supplier control and information management.

For staff, employees are the ambassadors, relationship builders and public face of her business. Hang Seng provides a wide range of staff training and development programmes. Depending on employees' position, training may cover financial knowledge, banking products and operations, compliance, risk management, leadership and management skills, and sales and relationship management. A comprehensive New Joiners induction programme is run for all new employees. A Leadership and Management Development framework is also established for talent staff to enhance their leadership qualities, people management capabilities and business and personal effectiveness skills. A Management Trainee programme gives graduates intensive training with the objective of grooming them to take up future management roles. Safe and dynamic working environment is provided for employees, and an open dialogue is maintained between manager and employee. Hang Seng also review the compensation packages and career advancement opportunities regularly for retention of staff.

c. As one of the largest banks in Hong Kong, Hang Seng is a local pioneer in promoting environmental responsibility. She strives to reduce waste production and energy consumption, and to use environmental friendly products and materials in operations. Key initiatives include Hang Seng Yunnan Biogas Project in China - helps to converse natural resources and protect environment bringing positive change to the lives of villagers, Hang Seng Pan Pearl River Delta Environmental Awards - aims to serve as a catalyst for positive environmental change among manufacturing companies, e-Banking services, Green Banking Integrated Account - promotes environmental awareness among full-time tertiary education students, and sponsorship of the Friends of the Earth (Hong Kong) 'Power Smart' Energy Saving Contest etc.

d. To have a positive impact on community, Hang Seng initiates and participates in a wide range of activities to promote social development, personal empowerment and long-term economic growth. Key activities include participating in activities of The Community Chest of Hong Kong, providing e-donation service for charitable organizations, organizing Regeneration Society Top Ten Regeneration Warriors Programme to promote positive thinking and self-belief philosophy to overcome life's challenges, participating in Hang Seng Bank Leaders To Leaders Lecture Series to provide youngsters direct dialogue with prominent community leaders on important social issues, providing scholarship to outstanding undergraduate students, and setting up Hong Kong Family Welfare Society Youth Mediation Scheme to help students building positive attitude to resolve conflicts with peers or family members etc. In promoting arts and culture and sports among youngsters, Hang Seng Arts Empowerment Workshops are organized for low-income families' students 
and Hang Seng Table Tennis Academy is established to nurture rising young table tennis stars.

With the broad spectrum of CSR practices, Hang Seng was the first bank to achieve an A+ rating in employing Global Reporting Initiative sustainability reporting guidelines. In 2013, Hang Seng was also once again recognized by Corporate Knights as one of the "Global 100 Most Sustainable Corporations in the World".

\section{Discussion}

Having reviewed the CSR practices of the 3 banking corporations, below is a summary listing the areas they specifically mentioned in their websites, sustainability or CSR reports (Table 1):

Table 1. Areas of CSR which HSBC, BOCHK, and Hang Seng specifically mentioned* (For those items with* mean that they heavily involve in)

\begin{tabular}{|l|l|l|l|}
\hline & HSBC & BOCHK & Hang Seng \\
\hline Environment & $*$ & $*$ & $*$ \\
\hline Climate & $*$ & $*$ & \\
\hline Sustainability & $*$ & & \\
\hline People / Community includes: & & & \\
\hline Investors / Shareholders & & $*$ & \\
\hline Employee & & $*$ & $*$ \\
\hline Education & $*$ & $*$ & $*$ \\
\hline Volunteering & $*$ & $*$ & $*$ \\
\hline Donation & $*$ & $*$ & $*$ \\
\hline Customers & & $*$ & $*$ \\
\hline Suppliers & & $*$ & \\
\hline Government & & $*$ & \\
\hline & & & $*$ \\
\hline Corporate Governance & & $*$ & \\
\hline
\end{tabular}

\subsection{Similarities and Differences}

Banks may use different names for similar area. Table 1 categorizes CSR practices into five areas: environment, climate, sustainability, people/community, and corporate governance.Regarding people / community, its coverage is quite broad - investors / shareholders, employee, education, volunteering, donation, customers, suppliers, and government. Both the 3 banking corporations have specifically mentioned and carried out CSR practices in the area relating to environment, education and volunteering.

For environment, they work hard to reduce waste remissions and energy consumption, and use energy-saving technologies and systems. For education, all 3 provide scholarship to students, and classes and activities for needed students. For volunteering, the 3 banks involve 
in organizing activities for community, participating in activities organized by charitable organizations, and having volunteer team to help elder, young or disabled.

For most of the items, at least two banks mentioned them in their reports; for instance, climate, employee, donation, customers, suppliers, and corporate governance. On the other hand, there are three items mentioned by one bank only: sustainability, investors / shareholders, and government.

In respect to sustainability, only HSBC has highlighted it as a single key aspect for discussion. It is about the sector policy created by HSBC in guiding the way it operates in these sectors which may have impacts on environment.

The other two items which specifically highlighted by BOCHK only are investors / shareholders and government. These parties are considered as stakeholders by BOCHK and engaging with them helps achieving business goals and CSR.

In terms of detail disclosure, BOCHK has clearer description about its CSR practices in more and different areas. For instance, BOCHK mentioned its engagement with various stakeholders in greater details.

\subsection{Relationship between CSR and Financial Performance}

Table 2. 2013 Financial Performances of 3 Banks (Source: KPMG Hong Kong Banking Survey 2014)

\begin{tabular}{|l|l|l|l|}
\hline (HKS in million) & HSBC & BOCHK & Hang Seng \\
\hline Total Assets & $6,439,355$ & $1,969,777$ & $1,143,730$ \\
\hline Total Equity & 522,224 & 147,943 & 107,778 \\
\hline $\begin{array}{l}\text { Total Deposits } \\
\text { from Customers }\end{array}$ & $4,254,752$ & $1,329,376$ & 824,996 \\
\hline $\begin{array}{l}\text { Net Profit after } \\
\text { Tax }\end{array}$ & 129,055 & 21,915 & 26,678 \\
\hline Profit before Tax & 144,756 & 26,545 & 28,496 \\
\hline $\begin{array}{l}\text { Net Interest } \\
\text { Income }\end{array}$ & 87,365 & 26,002 & 18,604 \\
\hline $\begin{array}{l}\text { Ratios (\%) } \\
\text { Rotal Capital }\end{array}$ & 15.2 & 15.8 & 15.8 \\
\hline Liquidity Ratio & 36.5 & 1.2 & 2.4 \\
\hline Return on Assets & 2.1 & 15.2 & 26.7 \\
\hline Return on Equity & 25.9 & 30.5 & 32.4 \\
\hline $\begin{array}{l}\text { Cost/Income } \\
\text { Ratio }\end{array}$ & 33.9 & & 34.9 \\
\hline
\end{tabular}


Having examined the current CSR practices in the top 3 licensed banks in Hong Kong, they in general put heavy focus in environment and people / community. These areas cover using energy-saving technologies, developing solution for better environment, donations, providing education, volunteering work, providing care to employees and customers etc. It is in general believed that companies with more assets and profit can put more resources into CSR. However, it is interesting to note that BOCHK and Hang Seng have put great effort in different CSR aspects even though their total assets, total equity, total deposits, profit before and after tax are far behind HSBC. In terms of ratio analysis, the ratios mentioned in Table 2 are comparable except return on assets and return on equity for the 3 banks. BOCHK has the lowest return on assets and equity. Therefore financial performance may not be the only determinants of having successful or all-round CSR practices.

\section{Conclusion and Recommendation}

The above discussion provides good examples for other banks which engaged or want to engage in CSR practices. Financial performance is not the only factor affecting the implementation of CSR. Bank having the highest profit or assets may not be the one who actively engages with various types of stakeholders. It may be a matter of determination and banks' care for the whole community and society and all stakeholders. Interested banks may start from small CSR practices, put resources on some easily achievable CSR practices initially, such as providing donations, scholarships, volunteering work and using less paper, and then expands to larger perspectives, such as changing production process, and investing in energy-saving projects, with the reference to above mentioned 3 banks.

In fact, businesses are running in an information-driven economy where their practices have become increasingly transparent, and all stakeholders have kept eyes on what they are doing. Businesses are under increasing pressure from various stakeholders that they have to demonstrate they get plans and strategies for sustainable development. Therefore, the trend of having CSR practices is unavoidable.

Governments should consider including CSR requirements in Companies Ordinance or Banking Ordinance in order to encourage banks to be more socially responsible, such as disclosure on environmental and social issues; providing incentives for banks doing CSR especially support tosmall and medium-sized ones. Incentives could be in form of tax deduction, government subsidy to companies in providing CSR training to employees or developing energy-saving products or adopting energy-renewable production process. Stock Exchanges should also consider requesting their listed companies to follow GRI guidelines or their self-developed CSR guidelines in CSR and sustainability reporting.

\section{Limitations and Future Research}

This study mainly uses secondary data for analysis. In future, questionnaire or interviews can be conducted with banks or public to collect primary data for analysis. Besides, this study adopts the 2014 Banking Survey of KPMG Hong Kong in selecting the 3 licensed banks for analysis. The ranking of these 3 banks may be different year from year. Future study can select banks from more recent survey result if available. Then the comparison of their current 
financial results will be more relevant. As the HKEx plans to make the ESG Reporting Guide mandatory to listed companies, future study can investigate the compliance and difficulties encounter.

\section{References}

BOCHK. (2013). 2013Corporate Social Responsibility Report, Bank of China Hong Kong (Holdings) Limited.

BOCHK. (2013). 2013Annual Report, Bank of China Hong Kong (Holdings) Limited.

Bebbington J., Larrinage C., \& Moneva J.M. (2008). Corporate social reporting and reputation risk management. Accounting, Auditing and Accountability Journal, 21(3), 337-361. http://dx.doi.org/10.1108/09513570810863932

Christensen L.J., Peirce E., Hartman L.P., Hoffman W.M., \& Carrier J. (2007). Ethics, CSR, and Sustainability Education in the Financial Times Top 50 Global Business Schools: Baseline Data and Future Research Directions. Journal of Business Ethics, 73(4), 347-368. http://dx.doi.org/10.1007/s10551-006-9211-5

Cruz L.B., \& Boehe D.M. (2008). CSR in the global marketplace: towards sustainable global value chains. Management Decision, 46(8), 1187-1209. http://dx.doi.org/10.1108/00251740810901381

Doukakis I.P., Kapardis M.K., \& Katsioloudes M. (2005). Corporate social responsibility: the way forward? Maybe not! A preliminary study in Cyprus. European Business Review, 17(3), 263-279. http://dx.doi.org/10.1108/09555340510596661

Freeman R.E. (1984). Strategic Management: a Stakeholder Approach, Pitman Publishing, Boston, MA.

Frankental P. (2001). Corporate social responsibility - a PR invention?. Corporate Communications: An International Journal, 6(1), 18-23. http://dx.doi.org/10.1108/13563280110381170)

Friedman M. (1962). Capitalism and Freedom, University of Chicago Press, Chicago, IL.

Ghillyer A. (2014). Business Ethics Now, $4^{\text {th }}$ edition, McGraw-Hill Education, New York.

Global Reporting Initiative (GRI), G4 Sustainability Reporting Guidelines, GRI, the Netherlands.

Gyves S., \& Higgins E.O. (2008). Corporate social responsibility: an avenue for sustainable benefit for society and the firm?. Society and Business Review, 3(3), 207-223. http://dx.doi.org/10.1108/17465680810907297

Hang Seng. (2013). 2013CorporateSustainability Report, Hang Seng Bank Limited.

Hang Seng. (2013). 2013Annual Report, Hang Seng Bank Limited. 
Hong Kong Exchanges and Clearing Limited. (2011). Initiatives in promoting corporate social responsibility in the marketplace by HKEx and overseas exchanges. Exchange, Oct 2011, p26-31.

Hoffman R.C. (2007). Corporate social responsibility in the 1920s: an institutional perspective. Journal of Management History, 13(1), 55-73. http://dx.doi.org/10.1108/17511340710715179

Holme C. (2010). Corporate social responsibility: a strategic issue or a wasteful distraction?.

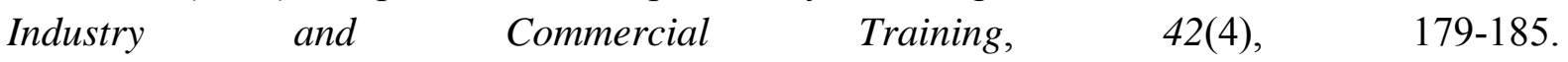
http://dx.doi.org/10.1108/00197851011048528

HSBC. (2013). 2013Sustainability Report, Hong Kong \& Shanghai Banking Corporation.

HSBC. (2013). 2013Annual Report, Hong Kong \& Shanghai Banking Corporation.

KPMG. (2014). Hong Kong Banking Survey 2014, KPMG.

Lance M. (2001). What do we mean by corporate social responsibility?. Corporate Governance, 1(2), 16-22.

Lanoizelee F.Q. (2011). Are competition and corporate social responsibility compatible? The myth of sustainable competitive advantage. Society and Business Review, 6(1), 77-98. http://dx.doi.org/10.1108/17465681111105850

Mandhachitara R., \& Poolthong Y. (2011). A model of customer loyalty and corporate social responsibility. Journal of Services Marketing, 25(2), 122-133. http://dx.doi.org/10.1108/08876041111119840

McWilliams A., \& Siegel D. (2001). Corporate Social Responsibility: a theory of the firm perspective. Academy of Management Review, 26(1), 117-127.

Preston L.E., \& O'Bannon D.P. (1997). The corporate social-financial performance relationship: a typology and analysis. Business and Society, 36, 419-429. http://dx.doi.org/10.1177/000765039703600406

OHK. (2010). Submission to the Financial Services and Treasury Bureau of the Hong Kong SAR Government on the Rewrite of the Companies Ordinance. Oxfam Hong Kong.

Olivia (2011). Difference between business ethics and social responsibility. Jan $24^{\text {th }} 2011$, (www.differencebetween.com/difference-between-business-ethics-and-social-responsibilty/).

Simpson W.G., \& Kohers T. (2002). The link between corporate social and financial performance: evidence from the banking industry. Journal of Business Ethics, 35, 97-109. http://dx.doi.org/10.1023/A:1013082525900o

Stanwick P.A., \& Stanwick S.D. (1998). The relationship between corporate social performance and organizational size, financial performance, and environmental performance: an empirical examination. Journal of Business Ethics, 17, 195-204. http://dx.doi.org/10.1023/A:1005784421547 
Yeung S. (2011). The role of banks in corporate social responsibility. Journal of Applied Economics and Business Research, 1(2), 103-115.

Yeoh P. (2007). The direction and control of corporations: law or strategy?. Managerial Law, 49(1/2), 37-47. http://dx.doi.org/10.1108/03090550710759667) 